\title{
Human Ecological Perspectives within a Residential Treatment Setting for Children
}

\author{
Douglas E. Wax \\ University of Michigan
}

To be or not to be, ecologically thinking, is a spatial question. Studies of plants (MacLeish, 1973), monkeys (Calhoun, 1962; WynneEdwards, 1962), and humans (Benzaquin, 1967) suggest that isolated existence as well as overcrowded habitation can be detrimental to the plants, animals, or persons concerned (McKenzie, 1968). In fact, readers and author alike will have experienced moments of insular and crowded conditions as a real threat to their livelihood-personally and professionally. For instance, it is most unusual that a person will relegate himself or herself to the center of an empty dining room, for the spatial expanse would dwarf a person. More likely, the person would seat himself or herself in the proximity of others but not amidst others, for overcrowding tends to annihilate the individual.

These very ecological and human factors also apply to life and work in residential settings. The use of residential territory is as much a function of the quality of interpersonal interaction as of the space available to residents and staff within the residential setting.

\section{Responses to Crowding}

In the residential treatment milieu, common responses to crowding are less severe than those observed in the animal studies cited, but can

Douglas E. Wax of the Children's Psychiatric Hospital, University of Michigan Medical Center, submitted this paper to Child Care Quarterly shortly before his untimely passing in June 1974. The editor wishes to express his appreciation to $C C Q$ consulting editor Henry W. Maier and to Fred Busch, who made the slight editorial corrections that were necessary to enable us to publish it. The author did not, of course, have the usual opportunity to review these changes.

Requests for reprints should be sent to Fred Busch, Children's Psychiatric Hospital, University of Michigan Medical Center, Ann Arbor, Michigan 48104. 
reach disastrous levels, often amplifying panic in staff and patients alike. Some of the obvious effects of crowding include: increased frequency of runaway (flight) behavior: suicide attempts and/or the mention of suicide; self- or mutual mutilation (self-destructive and possibly cannibalistic behavior); and a general breakdown in the decision-making process by staff, including instituting a variety of punitive measures previously disregarded and certainly considered unacceptable under "normal" circumstances.

A series of examples may illustrate the various levels of breakdown that may occur when the residential setting becomes surfeited with people. Sonny, a 13-year-old borderline psychotic, who usually kept to himself and was known to be making progress in his therapy, became obstreperous one evening when a full complement of ward staff and children were milling about before bedtime, quite literally with nothing to do. Sonny suddenly began to tear up his belongings and to threaten staff physically when they sought to intervene. Ward staff rallied quickly and made the decision that he should be placed in an isolation room located in a remote part of the hospital. There he was taken forcibly, remaining for what seemed to him an eternity. He sang his repertoire of tunes to pass the time, but all the while he harbored the fantasy that he would remain captive, forever abandoned in isolation. He later recounted this fear to his therapist, telling her that he assumed he would never get out of the room alive. Donald, another patient, had been admitted for diagnostic study due to his recurrent hostile and aggressive behavior. Quickly he learned that acting up within the residence meant being placed in an isolation room. However, he also discovered a new talent, that of springing the locks of the isolation room by pressing against its door in a certain manner. Thus, he was able quite effectively to frustrate staff and maintenance people alike, who were helpless to contain him. Both examples illustrate the varied means by which patients reacting to unusual territorial circumstances develop compensatory measures for psychological survival. Further, these examples suggest that the patient may have a counterimpact upon the milieu ecology, stirring or raising the level of anxiety, adding to already stress-laden situations, and, to a large extent, exerting control over the caretakers. Issues of competence, dominance, and even succession so often discussed in biological ecology are readily observable within the human ecosystem.

The impact of crowding upon the confined territory of the residential milieu is obvious to anyone who has had the opportunity to observe patient-staff interaction. Overstaffing, when occurring in a ratio of two or three patients to one staff person often results in pro- 
prietary and rather slavish attempts by children and ward staff alike to replicate the psychotherapeutic 1:1 model. Small-group activities in which four or five children may be engaged either spontaneously or under the leadership of a staff member not only fail to be encouraged but may be discouraged actively or passively by staff members who perceive their obligation as "engagement" with the children. When a shift in either patient or staff census results in a decrease of the ratio, both patients and staff feel threatened and deprived of what has been accepted as standard practice. The following vignette supports this hypothesis. After a long holiday weekend during which staff was at odds and unable to find things to do, having only four children in its charge but numbering seven, Miles, a relatively new ward staff member, was observed entering 10-year-old Peter's room. There, Peter had been engaged quietly, building a plastic race car model. Miles asked, "Say, Peter, can I give you a hand with that? Looks like you're having trouble with those decals. It sure is hard for you to do stuff like that!" And so the monologue proceeded. Shortly thereafter, Peter was reported to have flung the model race car against the wall, an action that precipitated the arrival of two staff who then placed Peter in an isolation room. One need not wonder here whether Peter had become a victim of territorial overcrowding. The staff-patient ratio on that particular weekend and at that particular moment led the well-intentioned Miles to seek some "purposeful" activity; the result was an invasion of Peter's territory both psychologically and physically. In such situations, it becomes impossible to separate the psychological territory from the physical territory. Lacking specific physical limitations such as doors on each room, a child's life space is constantly open to invasion by adult caretakers and peers. When McKenzie (1961) discussed the spatial proprieties of the human ecological environment, he carefully noted that the proprieties of an area have an immediate bearing upon its use and function. The example of Miles and Peter demonstrates graphically how milieu function and use become violated quickly in the absence of natural barriers to intrusion. Laws of territoriality are poorly defined or nonexistent under such circumstances.

Many of the children living within the residence attempt to make adaptations that will accommodate their need for private territory. Such accommodations include erecting barriers, paper screens, and beaded curtains. Some of the children even move their furniture in such a way that free passage and line of sight from exterior to interior are blocked. All of these examples are mere manifestations of a need on the part of the individual to create a space that is bounded 
and definite: a territory with the necessary safeguards for its inhabitant.

\section{Use of Open Areas}

Thus far, only one aspect of the broad spatial considerations within the residential milieu has been examined. Observations on the use of open areas such as the corridor, day room, and large play space over a six-month period gave rise to the hypothesis that certain spaces have implicit as well as explicit functions and carry built-in invitations to both staff and patients to behave stereotypically. The day room, for instance, fitted out with wall-to-wall carpet, a large color television set, and some lounge chairs, implicitly is the place for passive relaxation or entertainment. Large group-planning meetings may be held in this space as well. Certain other activities such as more active games, arts and crafts, and even conversation become taboo in this area, although there is no written rule that such things may not occur here. Often staff and children may be heard to say, "Hey, that doesn't belong here," or "You don't do that here," when someone brings equipment or engages in a mode of activity that fails to coincide with the "unwritten" rule. By contrast, a large, undecorated, unfurnished space at the end of the long corridor is used solely for activities such as bowling, dodge ball, boxing matches, and other largemuscle activities. A child wishing to read in this area or perhaps build a model or draw a picture is quickly discouraged, not only because the space lacks suitable furniture for the activity but also because his or her passivity would be impinged upon rapidly by the more active behavior of staff and peers. The hallway, often considered a "transitional" area, is a quasi-neutral zone. The bipolar opposites, activity and passivity, are ranged out at each end. The corridor also is the major avenue for social interaction and an unavoidable route necessitating contact among members of the residential setting. Much social activity and patient curiosity are focused mid-hallway, where on the one side is the nursing station and on the other the staff lounge. Though children are constantly shooed away from these two spots, they seem drawn to them as if by magic, attracted by the knowledge that these are the places where information is stored and shared, plans are made, and activity involving them occurs.

Indeed, a spatial hierarchy exists within the milieu. Priority is given to those areas occupied by highest-level staff. The lowest priority and attention as well as discretion are given to the kitchen and bathroom areas. Aside from the staff areas mentioned, the child's own 
bedroom or bed area occupies a high position, as demonstrated by the children's attempts to guard rooms and bed areas and to decorate and personalize them.

\section{Personalization of Life Space}

The various efforts by children to personalize their life space, an obvious reaction to the depersonalization experienced within the residential setting, deserves some attention. The degree to which the child and staff member become involved in the milieu is often related to the child's affective state. We have observed that the more depressed the child's affect initially, the less gratifying life is for the staff member, thus increasing the "overtime" investment of each. Dorothy, a severely depressed borderline child, demonstrated a range of responses that reflected her therapeutic progress and adaptation to the milieu. She arrived laden with suitcases and cartons stuffed to the brim with dolls, toys, and equipment from home. She even brought with her a small portable electric organ, a record player, and a number of posters depicting various popular musicians. These she immediately plastered on the walls of her room as if to populate that empty space with familiar faces. She arranged her various belongings about the periphery of the room, even filling the corners. Perhaps this was Dorothy's attempt to soften the harshness she perceived. Clearly, she behaved like a bird nesting with whatever she could bring. Several days later, however, she requested marker pen and paper. Later, she drew a variety of pictures and signs, peace symbols, words of love, hearts, and similar emblems. Despite this show of affection, reportedly she cried bitterly as each evening approached, complaining of homesickness and demanding to call her mother or some relative, anyone who might come to rescue her. All attempts to soothe her failed, and staff's interest in her decorations was met with tears and steely resistance to their overtures. Frequently, she spoke of running away and referred to her stay as planned and brief. Obviously, though, she came prepared for occupation with virtually all of her belongings. As time passed, with the evaluation period concluded and treatment begun, Dorothy gradually replaced the belongings from home with products she made in arts and crafts. She now chose to decorate her room with symbols appropriate to upcoming holidays and festivities organized at the residence. Her "settling in" seemed graphically indexed by the way in which she used her territory to express first the pain of separation and by her attempts to individuate within the residence. As she progressed, she devised means of expressing her own 
responsivity and role as "interior decorator" for the residence. Notably, a parallel process of adaptation was reported in her psychotherapy.

\section{Spatial Territoriality and Sustenance}

The issues of spatial territoriality are so intermeshed with those of sustenance within the milieu ecology that at once they seem obvious and yet, upon closer inspection, become hard to discern. Consumption-i.e., issues regarding the quantity, quality, and use of food-are constant discussion topics. Where food should be consumed, by whom it should be given, whether it should be used as a reward, who has taken too much, and who should store gift packages number among the repeated sustenance issues.

These issues became highly charged with the introduction of a therapeutic play group as a treatment modality designed for specific children whose difficulties involved particularly the expression of a strong affect by direct motor activity. The "play group," as it was called, met once a week to engage in fantasy role playing emphasizing discovery of ways to talk about feelings instead of immediately acting upon them. The ultimate goals of the treatment group involved assisting these children in finding ways to verbalize affects. One part of the "settling" ritual concluding each session was usually a treat in the form of candy, cookies, or similar goodies that could be shared by the group. Quite extensive hoarding occurred, and issues concerning the apportioning of treats arose, particularly at the outset of the project. However, when this behavior spilled over into the milieu following these meetings, sustenance issues and conflict emerged there as well. Children and staff became indignant, irate that others were not made privy to such largess. Rules were considered and sanctions were imposed upon group members and therapist as well regarding the carryover of group activities into the residence. Little or no discussion could be generated around the obvious transitional value that the food held for the children. The conflict was deflected to an extent by the ward administrator but not resolved per se. Eventually, a rule was made that any group's food in the form of treats was to be reserved for that activity area only.

Questions such as "Will I be fed?" "By whom?" and "How great is the supply?" could not be pursued effectively in this instance, specifically because of the sustenance issues and the competition generated. Though deprivation was a real issue for those who were not group members, ward staff and patients were unable to find compensatory 
measures to resolve their conflict. The impact upon the total milieu created by several children's access to a perceived cornucopia of food tipped an already tenuous balance. In McKenzie's terms (1968), the mutual adaptation by competing systems - the group members and the nongroup members-was upset by the introduction of the treats. Righteously indignant nongroup members claimed the situation was unfair, and failing an abortive "sit-in" designed to disrupt the group, many retreated to attacking group members, stealing their supplies, and similar hostile behavior. Until a new equilibrium was struck by instituting a variety of alternative group activities, each with an allied advantage, the disruptive aspect of the play group upon the nongroup members and staff continued.

\section{Environmental Accommodation}

Ecological equilibrium is based upon the capacity of the inhabitants to accommodate, be they plants, animals, or human beings. However, human beings differ from plants and animals in a variety of capacities. Although each may control his environment, only humans desire to control it and consciously seek ways to create a new environment (McKenzie, 1934). The unique feature of human ecology is the function of human conscious and unconscious process bent toward environmental accommodation.

The impact of new agents upon the therapeutic milieu has been well documented by a number of observers (Bettleheim \& Sylvester, 1948; Portnoy, 1973; Redl, 1966). Specifically, Bettleheim (1950) sees the maintenance of continuity by specific time commitment on the part of child care staff as necessary for the effective treatment of severely disturbed children. Essentially, constancy and consistency are the ideal therapeutic basis for the residential milieu. The stability of the human object environment is essential to the establishment of basic trust for children with serious deficits in the areas of object constancy, object relations, and maintenance of impulse control (Redl \& Wineman, 1951).

The entry of new personnel into the residential milieu has a profound impact upon children and staff alike. Several observations may indicate the dimensions of this process. At the first staff meeting held by a new ward administrator, one child care worker left duty abruptly, peeked into the conference room, and then excused himself in an embarrassed manner, saying, "I just wanted to see what Dr. W. looks like." The new administrator was immediately reminded of the Chicago Tribune Christmas editorial that ended, "Yes, Virginia, there is 
a Santa Claus." The instance serves to highlight not only staff's curiosity but their disbelief that the person about whom they have been talking, around whom they have been weaving fantasies, does in fact exist and has arrived. Similarly, the children's anticipation was observable and varied. When one staff member attempted to introduce the new administrator to a young female patient by inquiring, "Have you met Dr.W.?" the 9-year-old promptly turned on her heel, shrugged one shoulder in a coy manner, and said, "Oh, yes, many times before." She even denied his status as a newcomer to the milieu. A second child being asked the same question threw both hands about in despair and yelled, "Dr. W., yeech!" Because the previous administrator had also been her therapist, her reaction was understandable when she immediately went on to say, "Where is Dr. T., anway?" In this instance, the girl's response illustrates the tendency to reject the new agent as an invader and to seek restoration of the former balance within the system.

A spectrum of ambivalence within the accommodative/assimilative process is best illustrated by Bill's response. Upon introduction, this early adolescent shook hands with the new administrator. During administrative rounds the following day, Bill attempted to strike up a casual conversation with the newcomer. On a third morning, he encountered the administrator on the outdoor basketball court and proudly introduced him in a familiar back-slapping, affectionately toned manner to a friend from a different part of the residence. One week later, Bill made up a play on words, punning on the ward administrator's name in a playful, bantering fashion. However, in the third week, this very same boy responded to the administrator's salutation with angry defiance, challenging, "Hey, how do you know my name, anyway?" From then on, Bill's indignation surfaced in a variety of ways, revealing his resentment of the newcomer as an intruder, someone who would potentially disrupt the system by imposing new rules and thereby change the life style of the residence.

If a demonstrable disruption to the balance of the milieu ecology occurs when new agents are introduced, another type of influence far more obscure-an effluvium of unwritten rules-virtually smothers the environment. Few if any rules are actually posted in the milieu, and generally the notion of a therapeutic community in which staff and patients are encouraged to "work out" the solutions to life's dilemmas is an integral part of the program. However, a survey of staff on acceptable dining behavior revealed that sustenance issues were heavily bound by stringent unwritten rules. The "ideal" child dining room behavior appeared not unlike the Victorian standard for 
decorum. The following categories were surveyed: before dining, in the dining room, food use, and leaving the dining room. The frequency of certain rules delineated the following profile. The child will have washed his or her hands and be dressed in proper clean clothes before dining. He must exhibit proper table manners and in particular not change his seat once he has chosen one. If he does not eat a substantial main course, he will be denied dessert or restricted from having a snack in the evening. Further, he is required to drink his glass of milk before having dessert or special treats. Finally, after clearing his place setting, he must ask to be excused by a staff member before leaving the dining room. Notably then, a rigid code is embroidered around sustenance. However, that code is absolutely spontaneous, having no "official" status within the therapeutic milieu design. Here, in a sense, the whole notion of a nurturant, benign therapeutic milieu designed to enhance the health and physical well-being of its patients is governed by an invisible but existent set of structures that form an implicit system governing its inhabitants. In essence, this concluding example demonstrates the powerful covert ecosystem and may unfortunately represent the behavioral standard to which the milieu patient must accommodate before he or she can be perceived as "successful" and cured.

\section{Conclusion}

Attempts to understand the workings of a children's residential treatment milieu through the application of human ecological principles may offer a variation in perspective toward residential treatment in general. The attempt to apply a social systems approach to such a setting is neither unique nor particularly new. However, as in Darwin's classic "Cats and Clover" illustration of the interrelationship among seemingly disparate elements in an environment, the application of ecological principles can offer insights that might otherwise escape our scrutiny.

Typically observant and curious, Darwin noticed that heartsease, a strain of clover, was failing to flourish in a region where hitherto it had abounded. Making careful observations, he discovered that only one species of bee, the humblebee, pollinated heartsease. Other bees avoided its red flower. If, then, the humblebee population was declining to extinction in the area, the heartsease would follow a similar fate. Darwin was not satisfied to stop his investigation at this point. Rather, his continued observations led to the discovery that the number of humblebees in the district was related to the field mouse popu- 
lation. A large population of mice with a particular appetite for honey meant the destruction of the humblebee's honey combs, hence decimation of that bee population. But those areas bordering on towns and villages seemed immune from heartsease clover loss-there, the crop flourished. Darwin reasoned and observed that these inhabited areas were amply populated with house cats hunting field mice, which in turn diminished the threat to the humblebee hives. Thus, Darwin discovered that to a large extent heartsease clover crop survival depended upon the number of cats, perhaps kept by the maiden ladies of the inhabited areas.

This whimsical anecdote illustrates the obvious need for careful observation on the part of anyone wishing to understand the intricate relationships among elements of a system. The residential treatment milieu readily offers itself for such analysis and should yield understanding of and answers to its own problems, if we take the effort to observe with care and discern its complicated interdependent elements.

\section{References}

Benzaquin, P. Fire in Boston's Coconut Grove. Boston: Brandon Press, 1967.

Bettleheim, B. Love is not enough. Glencoe, Ill.: Free Press, 1950.

Bettleheim, B., \& Sylvester, E. The therapeutic milieu. American Journal of Orthopsychiatry, 1948, 18, 191-206.

Calhoun, J. A "behavioral sink." In E. L. Bloss (Ed.), Roots of behavior. New York: Harper \& Row, 1962.

MacLeish, K. Exploring Australia's coral jungle. National Geographic, 1973, 143, 743-793.

McKenzie, R. D. Human Ecology. Ann Arbor, Mich.: George Wahr, 1934.

McKenzie, R. D. The scope of human ecology. In G. A. Theodorson (Ed.), Studies in human ecology. New York: Rowe, Peterson, 1961.

McKenzie, R. D. On Human Ecology. Chicago: University of Chicago Press, 1968.

Portnoy, S. Power of child care worker and therapist figures and their effectiveness as models for emotionally disturbed children in residential treatment. Journal of Consulting and Clinical Psychology, 1973, 40, 15-19.

Redl, F. When we deal with children. New York: Free Press, 1966.

Redl, F., \& Wineman, D. Children who hate. New York: Free Press, 1951.

Wynne-Edwards, V. Animal dispersion in relation to social behavior. London: Oliver \& Boyd, 1962. 